\title{
On the Differences of Early Utopian Visions Between China and Western Society*
}

\author{
Written by SHI Ran, Trans. by YU Ya-ping \\ Zhejiang University, Hangzhou, China
}

\begin{abstract}
Utopian visions between China and Western society differed in their early stage. Words reflecting early Chinese utopian visions scattered in many ancient classics. Most of them were general depiction of an ideal society featured with equality, sympathy, preference for community autonomy and the social order "the whole world as one community". Early Western society witnessed many utopian monographs. Most of them offered detailed construction of social frame with emphasis on social function division, request for ideal authority, and property co-ownership as core of an ideal society.
\end{abstract}

Keywords: Utopia, Chinese and Western Civilizations, Visions

All Human civilizations "struggled, are struggling and will struggle from the very bottom of the same cliff for the common goal high above", and without exception with an ideal of utopia, "for certain function of utopia is manifested in the process of the world construction involved by substances with objective possibilities"2. However, utopia formed in social practice showed its differences in China and Western society due to different natural environment, demographic factors as well as means of material production. Utopia existed early in the human history, endowing the origin of different utopia situations in the two civilizations. Various texts have shown us how utopia differed in China and Western society.

\section{Depiction of the Reality Versus Design of Forms}

Rare monograph on utopia was found in ancient China, while fragmentalwords and sentences about an ideal society scattered in many classic books. These letters scarcely offered details of an ideal society, but displayed a harmonious society as a whole.

When it comes to China's utopia, the earliest must be the one described in the article "Li Yun" in The Book of Rites, a book mainly recording pre-Qin ritual systems. But a paragraph in "Li Yun" briefly described the vision of people with lofty ideals towards dream society, which read, "perfect society" is co-owned by all citizens where the noble and the talented are selected; where faith and harmony are sought. In this society,

* Acknowledgements: This paper was funded by: (1) the project "Chinese Contemporary Idea of Tragedy" and its Development, the number of the funding project is 14AZW004; (2) China National Find of Social Sciences "the Research of Fundamental Problems of the Contemporary Aesthetic and Criticism Forms" (15ZDB023).

SHI Ran is a doctor of judicial science, and a postdoctoral research assistant in the Department of Chinese Language and Literature, School of Humanities, Zhejiang University. His research field covers Marxism aesthetics and cultural theory.

YU Ya-ping is a Ph.D. candidate of the School of International Studies, Zhejiang University. Her research field covers British \& American literature and Comparative poetics.

1 Toynbee. Historical Studies, Book 1. Shanghai: Shanghai Century Publishing Group, 2010: 242.

2 Bloch, Ernst. The Principle of Hope, Book 1. Shanghai: Shanghai Translation Publishing House, 2012: 204. 
people not only support their parents, but others'; not only take care of their children, but others'. In this society, the seniors have houses to spend their remaining years in comfort, the young adults have jobs to support their families and the children have places to flourish. In this society, those who have lost their spouses, parents, and children or even lost their ability to work are supported by the community. In this society, all the men have satisfactory jobs and all the women have sweet homes. In this society, discarding the goods is hated, while hiding them for oneself is also not appreciated. In this society, citizens are willing to struggle for the public instead of private affairs. In this society, all the evil things like theft, revolt and harm are absent, doors are unbolted at night and honesty prevails throughout." ${ }^{3}$ This unfolded a social blue print "Datong". In ancient China, utopia was a society with great harmony. This passage in "Li Yun" depicted a harmonious society where all people could do their best and enjoy the proper place; however, no detailed social systems were designed. In Laozi's Dao De Jing, an ideal community was created featured with "a small state with a small population". A detailed and delicate design of social systems and the methods of production and living were absent and the very few words like "people feel greatly satisfied with the food they are eating, the clothes they are dressing and the customs they are having"4 help us get a glimpse of utopia. In Zhuangzi, similar description of utopia was made, "within the country, people will feel happy and stable if they are benefited from the public fortune with equality" . However, despite the scattered depiction of utopia bits and pieces by Chinese intellectuals, the history witnessed its frequent emergence in various records. "Huaxu State" and "Zhongbei State" inLiezi, "The Land of Peach Blossom" by Tao Yuanming (365-427) who lived in East Jin Dynasty (220-589), "An Island State" by Wang Yucheng (954-1001) in North Song Dynasty (960-1127), "ASecluded Place in Xijing" by Kang Yuzhi in South Song Dynasty (1127-1279) and "Junzi State" by Li Ruzhen (1763-1830) in Qing Dynasty (1636-1912), all portraying in essays and tales harmonious societies with happily-living and equally-treated people. Compared with romantic daydreams by intellectuals, Chinese working people proposed clearer plans and put them into practice. Zhang Jiao (?-184), for example, a leader of the Yellow Turban Uprising (a peasant uprising outburst in the year 184 of the late Eastern Han Dynasty), put forward utopian scheme in Taiping Jing (The Scripture of the Great Peace), with the main idea of "the properties in the world are co-owned by all who contribute their part with industry," political power and Yishe (houses offering accommodation for free) as the mode of property distribution. Of course it was not common in peasant uprising in China until the outbreak of Taiping Rebellion (1851-1864) in Qing Dynasty, with "the Land System of the Heavenly Kingdom" as the peak of peasant uprising in Chinese history, which was the first completed plan for the utopian society in China.

Despite the absence of a detailed design of the society, utopia in ancient China showed a general picture with its own characteristics. In this society, "those who are old are respected and supported; those who are ill are treated and cared; young students are well educated and all people are comfortably settled". In this society, "all people can do their best and enjoy the proper place", which is the keynote of an ideal society for Chinese people, showing Chinese aesthetic principles of Zhonghe (moderation and harmony), Shangtong (identifying with the superior), and the whole world as one community.

\footnotetext{
3 "Li Yun", a passage of The Book of Rites.

4 The 80th Chapter of Laozi's Dao De Jing.

5 "Heaven and Earth", a passage of Zhuangzi.

6 Taiping Jing, the $67^{\text {th }}$ Volume.
} 
Early Western society had many utopian monographs. They depicted detailed construction of social frame with splendid social living elements and neat formation of systems.

In the West, the image of utopia found its origin in ancient Greece, when Greek poet Hesiod (generally thought by scholars to have been active between 750 and 650 BC) in his "Works and Days" created a "golden age" under the rule of Kronos. In this country, "they lived like gods, and their hearts were entirely carefree, distant strangers to labor and suffering. Neither did wretched Age overtake them; instead, their members intact and unchanged, they took much pleasure in banquets and parties, apart from all evils till they died as if sleep overcame them. And everything worthwhile came to their hand, as the grain-growing earth bore fruit without tilling, plenty of good food crops unbegrudged; so they lived at their pleasure, peacefully minding their own business, amid numerous good things. Wealthy in flocks were they and beloved of the blessed immortals." ${ }^{\prime 7}$.In Theodore's fantasy novel, a voyager Bruce Young foundthe "Island of the Blessed". In this story, elaborate descriptions were made on the shape of the island, the environment, the residents, the living style and the mode of production, each coinciding with communist system labeled as collective production and consumption. One of the greatest Greek thinkers Plato (427-347BC) designed the republic based on the dialogues. As Plato once said, "we are fashioning the happy State, not piecemeal, or with a view of making a few happy citizens, but as awhole; and by-and-by we will proceed to view the opposite kind of State. Suppose that we were painting a

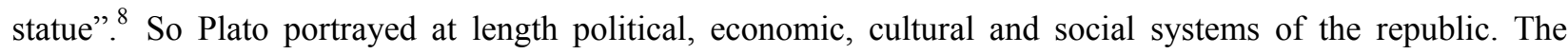
social ideal of the ancient Greeks was the starting point of the Western Utopia. Later the Western Renaissance witnessed the birth of three great works on utopian socialism: Utopia by English social philosopher Thomas More (1478-1535), The City of the Sun by Italian philosopher Tommaso Campanella (1568-1639) and Description of the Republic of Christianopolis by German theologian Johannes Valentinus Andreae (1586-1654). With Splendid ideas weaved in extraordinary literary writing, these three works were "Three Pearls" of early utopian socialism in the West. In the works, three utopian socialists blocked out their ideas for the formation and the organization of a communist society: from the common property system on the macro level to the mode of production on the micro level; from democratic political systems on the macro level to city planning, education, science, family life on a micro level. As a scholar once said, "one important contribution that utopian socialists have ever made was their emphasis on the practicability of social institution." "9

In the West, the monographs on utopia were rich in content, portraying elaborately the organizational forms of "island" or "city-state", designing various completed plans for an ideal society and manifesting Western aesthetic principles featured with elegance, delicacy and grace.

\section{Equally Interdependence Versus Functional Division}

The society is weaved by human relationship. Utopia differed in this respect. In ancient China, an ideal society was strongly featured with equality and interdependence, while in the West, the functional division was emphasized.

Early Chinese utopia was actually a "Datong" society (a society with great harmony), a self-reflection of the real society at that time. The keywords of Datong society were equality and interdependence. The article "Li Yun" in The Book of Rites had pointed out, "in this society, people not only love their relatives and family

\footnotetext{
7 Volgin, Viacheslav Petrovich. On Utopian Socialism. Beijing: China Renmin University Press, 1959: 16.

8 Plato. Republic. Beijing: The Commercial Press, 2002: 133.

9 Hertzler, J. O. Utopian Ideology. Beijing: The Commercial Press, 1990: 280.
} 
members but others', not only take care of their own children but others'...All those who have lost their spouses, children, relatives or lost their ability to work will be supported and taken care of by others, which actually is a harmonious interpersonal relationship." In Liezi, some states set examples to present ideal classless society. Huaxu State "is where people have no self-interest, private likes and dislikes" ${ }^{\text {, }}$; and in Zhongbei State, "people never compete for material goals, with the young and the old coexisting in a harmonious manner." a "Secluded Place in Xijing" by Kang Yuzhi, "people with different surnames live in great harmony"12. In the long history of China, the laboring masses had strongest request for the equality of property and social status. Early in Qin Dynasty, a famous peasant uprising lead by Chen Sheng (?-208BC) and Wu Guang (?-208BC) broke out with the slogan, "how can our birth prevent us from becoming princes and barons, generals and ministers?" Taiping Jing (The Scripture of the Great Peace) proposed in Taiping Rebellion (1851-1864) was strongly against wealth disparities and called for the co-ownership of property ${ }^{13}$. Besides, interdependent coexistence was promoted and the wise, the strong and the young were not allowed to bully their counterparts ${ }^{14}$. Zhong Xiang (?-1130), another leader in a peasant uprising in South Song Dynasty, explicitly pointed out, "the law emphasizing the difference between the high and the low, the rich and the poor is not appropriate. I am practicing the law to eliminate the distinction." 15 According to a famous Russian communist revolutionary Lenin (1870-1924), "the thought of equality is the most revolutionary for it struggles against the old autocratic social system." ${ }^{\prime 16}$ The thought of equality in the history of China had great significance for Chinese were born to be revolutionary. The thought of equality united all people to be sisters and brothers, the social relationship turned to a harmonious side.The progressive proposals raised in the long history of Chinese history all manifested the social ideal of the laboring people, from "loving and benefiting each other" raised by Mozi in Spring and Autumn Period (770-221BC) to the slogan of peasant uprising lead by Fang La (1078-1121) in North Song Dynasty "people all contribute to relieve the family with great difficulty and sufferings" the slogan of Taiping Rebellion "all people in the society share the food, clothes, money and enjoy the great peace as one family".

The situation in the early Western society was quite different from Chinese with its developed commercial business and complex division of labor. In the Western utopian society, functional division was interpreted from two perspectives, one vocational and the other hierarchical. Early in "The Island of the Blessed", Bruce Young had visualized a society with elaborated divided social functions, where "residents are divided into small groups based on blood relation, each less than four hundred...some fishing, some handcrafting etc.; all frequently rotated" ${ }^{18}$. Division of labor was the very principle for Plato to organize his republic. In his Republic, "each person will be happy engaged in the occupation that suits him best. If the city as a whole is happy, then individuals are happy." 19 Besides, division of classes was made in republic. Plato divided citizens into three types: wisdom-dominated, spirit-dominated and desire-dominated. An ideal society had two different groups

\footnotetext{
10 "Yellow Emperor", a passage of Liezi.

11 "Tang Wen", a passage of Liezi.

12 A Dream Record-The Literary Sketches by Kang Yuzhi of South Song Dynasty.

13 Taiping Jing, the 67th Volume.

14 Taiping Jing, 120th-136th Volumes.

15 The Chronicles of Emperor Gaozong's Government of South Song, the 76th Volume.

16 The Collected Works of Lenin, the 16th Volume.Beijing: People's Publishing House, 1988: 203.

17 The Chronicles of Emperor Gaozong's Government of South Song, the 76th Volume.

${ }_{18}$ Volgin,ViacheslavPetrovich. On Utopian Socialism. Beijing: China Renmin University Press, 1959: 21.

19 Plato. Republic. Beijing: The Commercial Press, 2002: 138.
} 
and three classes: guardians and labors; philosopher, warriors and labors. In the utopian state conceived by Thomas More, private ownership was abolished, and property was not only owned by certain class, but by all. People worked together and were endowed with equal rights. Rural-urban differences had long disappeared. However, slave class still remained in this state. In the social system designed by Tommaso Campanella, laboring masses shared property ownership. The majority of citizens had equal status economically, politically and culturally. While deeply influenced by Plato, in the City of the Sun, a shadow of aristocratic class remained for priesthood was set as a social system. In Christianopol is designed by Johannes Valentinus Andreae, slave system in Thomas More's utopia and priest class in Tommaso Campanella's the City of the Sun were absent. No one was allowed to own more property than others". But detailed vocational division was made: "The whole city is a workshop with a wide variety of arts and crafts"20

\section{Community Autonomy Versus Ideal Authority}

In ancient Chinese utopia societies, no authorized ruler was witnessed and the community was self-governed, totally contrary to the severe social reality with harsh authoritarian system. In Laozi's Dao De Jing, utopia was featured with "a small state with a small population... where weapons and armors can't find a right place to display" ${ }^{\prime 2}$, which means strong state apparatus as army found no opportunity to show its great strength. In The Book of Rites, an article named "Li Yun" proposed a concept of "a society of great harmony" (Datong in Chinese ), portraying a society where the whole world was considered as one community and the able and virtuous men were chosen, who were "definitely not the king and officials in the real society." 22 In Liezi, a state named Zhongbei clearly denied a king-subject relationship. "The Peach Blossom Source" by Tao Yuanming in East Jin Dynasty, "An Island State" by Wang Yucheng in North Song Dynasty and "A Secluded Place in Xijing" by Kang Yuzhi in South Song Dynasty all portrayed a self-governed community without authority and power. In the period of Three Kingdoms (220-280), a famous poet Ruanji (210-263) said, "in a place without an emperor, all the things will be in control; in a place without ministers, millions of affairs can be solved", and a great thinker Bao Jingyanin Jin Dynasty (265-420) put forward a concept of "a country with no emperor and no ministers where people have a stable and happy life and show obedient and awesome attitude towards the God and the land." In this country, "people are rich in food and clothes and have no need to compete with external forces"23. In South Song Dynasty, Deng Mu (1246-1306) proposed to "remove state officials and county magistrates, letting self-autonomy find its way out" ${ }^{\prime 24}$, clearly expressing his idea of removing state apparatus to fulfill the goal of community autonomy. Apart from intellectuals, working people were also aware and raised a social ideal without authority. Zhang $\mathrm{Lu}$, for example, a leader of the Yellow Turban Uprising, put forward and practiced an idea that "the whole society is under the administration of different levels of Jijiu (pious religious followers) instead of traditional senior officials",25.

Quite differently, the cases of Western utopian societywas more as the reflection of the reality. They didn't deny the authority; instead they were seeking for the perfect authority. On the "Island of the Blessed", Bruce

\footnotetext{
${ }^{20}$ Andreae, Johannes Valentinus. Description of the Republic of Christianopolis. Beijing: The Commercial Press, 1991: 30.

21 The 80th Chapter of Laozi's Dao De Jing.

${ }^{22}$ Peng Ming. From Utopia to Science: a Historical Research on the Development of Chinese Socialist Thoughts. Beijing: China Renmin University Press, 1991: 42.

23 "Jie Bao" a passage of Bao Puzi.

24 "The Way of Being an Official", a passage of Boya's Heptachord.

25 "The Biography of Zhang Lu", a passage of Romance of Wei during the Three Kingdoms.
} 
Young insisted, "the eldest was the authority, while others needed to obey."26 The ruler of the Republic was the philosopher-king. Plato had clear cut of different classes. The city consisted of two social groups, guardians and labors. The ruler was selected from the guardians. According to Plato, the ruling group was the spiritually supreme leader, so an ideal state should be ruled by wisdom-loving philosopher. Once philosopher-king became the ruler, the ideal city was leveled by philosophers, warriors and labors. As a thinker advocating slave system, Plato preferred Aristocracy rather than Democracy. Republic pointed out, "a true philosopher with understanding of forms will facilitate the harmonious co-operation of all the citizens of the city. This philosopher-king must be intelligent, reliable, and willing to lead a simple life. However, these qualities are rarely manifested on their own, so they must be encouraged through education and the study of Good"27, which was obviously a far cry from the idea raised by Chinese thinker in ancient times, "all people have opportunity to be great person like ancient Kings Yao and Shun". "Three Pearls" of early utopian socialism with distinctive names, terms and ways to organize the society, shared common interest in the selection of an ideal authority to control public affairs. Thomas More, following the tradition of Plato, let his utopia ruled by a wisdom-loving philosopher king, with senate as the organ of supreme power. Certainly, Thomas More's Utopia was featured with a fair degree of democracy: "Thirty families choose every year a magistrate, who was anciently called the syphogrant, but is now called the philarch; and over every ten syphogrants, with the families subject to them, there is another magistrate, who was anciently called the tranibor, but of late the archphilarch. All the syphogrants, who are in number 200, choose the Prince out of a list of four, who are named by the people of the four divisions of the city... ${ }^{, 28}$ Despite the fact that the prince and the tranibor once chosen will not be dismissed at will, the democratic political system at that historical period was quite advanced. Likewise, the deep influence of Plato was reflected in Tommaso Campanella's design of the City of the Sun, where the supreme ruler was "Sun", a priest, who actually was a philosopher-king. Three leaders ranked under "Sun" were respectively "power" in charge of military affairs, "wisdom" in charge of art, handcraft, and science, and "love" in charge of reproduction. ${ }^{29}$ Of course, certain degree of democracy could be found in the city, as People's Assembly can decide job candidates and criticize and depose the ruler. In Johannes Valentinus Andreae's Christianopolis, monarchy was denied, oligarchy was appreciated, and triumvirate was formed: "triumvirate was at least a most stable regime form, consisting of the most excellent and experienced citizens" 30 . Eight government officials and twenty-four senators were selected from the citizens with outstanding talents.

\section{Social Order Versus Property Relation}

Different backgrounds of writing lead to the differences in the content of early utopian literature in the West and in China. In ancient China, the society was mainly dominated by agricultural economy. Commodity economy had not gained its independent status yet, "hiding behind feudal natural economy."31 "Small-scale farming economy was manifested in politics as executive power dominated the whole society" 32 . The self-sufficient mode of production turned out to be "the most tenacious and enduring,"33. In this social form,

${ }^{26}$ Volgin, Viacheslav Petrovich. On Utopian Socialism. Beijing: China Renmin University Press, 1959: 21.

27 Plato. Republic. Beijing: The Commercial Press, 2002: 151.

28 More, Thomas. Utopia. The Commercial Press, 1982: 54.

29 Campanella, Tommaso. The City of the Sun. The Commercial Press, 1960: 19-22.

30 Andreae, Johannes Valentinus. Description of the Republic of Christianopolis. Beijing: The Commercial Press, $2005: 43$.

31 Qi Tao. Economic History of Ancient China. Jinan: Shandong University Press, 2011: 357.

32 Collected Works of K.Marx and F.Engels Volume 2. Beijing: People's Publishing House, 2009: 567.

33 Collected Works of K.Marx and F.Engels Volume 46. Beijing: People's Publishing House, 1974: 481. 
Chinese people had suffered disastrous exploitation and oppression, manifested in the unequal social relationship. Lenin said, “'working for other people' proved the existence of exploitation, which would ignite the ideal among the exploited and some intellectuals to struggle against this system." ${ }^{34}$ Chinese ancient intellectuals deeply felt from their own experience the unreasonable social order, war chaos and oppression resulting from feudal separationist rule. They showed their concern over property order, one of the patterns of social order, while private ownership was the corner beyond their reach, limited by the class they were in. As a result, "the world as one community" had special connotation. "Datong" society described in the article "Li Yun" in The Book of Rites was a typical ideal society for ancient China, presenting a picture of social order of a harmonious society featured with "the world as one community". While the property order, as an important part of the social order, was mentioned only in one sentence without any emphasis, "discarding the goods is hated, while hiding them for oneself is also not appreciated" $"$. From the sentence, a slight conclusion can be made that in "Datong" society, property was publicly owned, and the author himself took property lightly. In Liutao, or Six Secret Strategic Teachings of Taoism, "the world is not for a single person, but for all...It is mercy that allows all people to share the world consisting of heaven and earth with four seasons and great fortune. The ruler with mercy will win the world" "36. "Sharing fortune and property" was only one aspect of "the world as one community". "A Secluded Place in Xijing" by Kang Yuzhi mentioned, "in this place, clothes, food, livestock, silk, and fiber are shared by all, and are not allowed to be privately owned", which elaborated the idea of sharing the means of livelihood. However, similar proposal was rarely found in early utopian works of ancient China. "A small state with a small population" in Laozi's Dao De Jing, "Huaxu State" and "Zhongbei State" in Liezi, "The Peach Blossom Source" by Tao Yuanming, "An Island State" by Wang Yucheng, etc., gave no clear account of property ownership. However, Chinese ancient intellectuals had strong vision of an ideal society with equality. Peasants could directly feel the wide gap between the rich and the poor, while small scale producers focused only on equal distribution of land due to their limited class vision, rarely designing a whole set of property sharing, Zhang Lu's "Yishe" system (houses offering accommodation for free) being an exception.

In early Western society, the frequent production and exchange of commodity equipped people with a strong sense of property. At the meanwhile, complex social division of labor, distinct stratification and sharp social conflicts caused by poverty weaved together, providing a social background for the utopian ideal. "Some evil phenomenon in the society is attributed to private ownership, thus a conclusion is made that utopian communism is a necessary condition for a blessed society even though it can be found nowhere in the reality. ${ }^{, 37}$ Plato in Republic had elaborated that "Private property will ruin the honor of state. These men will by all means waste materials, violate laws and do all the evils, so do women." 38 Plato actually was an advocator of property sharing among guardians. Since the appearance of capitalist mode of production, the evil side of Western society exposed itself. The intellectuals with foresight revealed the private ownership was the root of all evils. Thomas More pointed out in his Utopia, "there will be two sorts of people among them, who deserves that their fortunes should be interchanged; the former useless, but wicked and ravenous; and the latter,

\footnotetext{
${ }^{34}$ The Collected Works of Lenin, the 1st Volume. Beijing: People's Publishing House, 1984: 377.

35 "Li Yun", a passage of The Book of Rites.

36 "Wen Shi", a passage from Liutao.

37 Volgin, Viacheslav Petrovich. On Utopian Socialism. Beijing: China Renmin University Press, 1959: 15.

38 Plato. Republic. Beijing: The Commercial Press, 2002: 321.
} 
who by their constant industry serve the public more than themselves, sincere and modest men. From whence I am persuaded, that till property is taken away there can be no equitable or just distribution of things, nor can the world be happily governed: for as long as that is maintained, the greatest and the best part of mankind will be still oppressed with a load of cares and anxieties." extreme poverty is the root of meanness, impudence, trick, theft, and cheat; treasure is also a root to cultivate pride, impudence, trick, exaggeration and selfishness." ${ }^{40}$ Early utopian socialists designed co-ownership of property in a clear and completed way, aiming at the abolishment of private ownership. The Western utopian literature elaborated every corner of an ideal society, with co-ownership of property as the core and other social systems as derivatives.

According to В.С. Стёпин, "culture is a method of social historical experience passed down, which is about human life and super-biological procedure." ${ }^{41}$ The differences of early utopian visions between China and Western society will in the long run influence the historical tendency of the two civilizations, passing down from generation to generation their cultural DNAs. It can't be denied that the contemporary world has changed dramatically, "the spiritual fortune of all nations becoming common property and national one-sidedness finding itself in a blind alley. As a result, world literature has been formed, binding national and local literature together, ${ }^{\text {, } 2}$. China and the Western society can benefit from the fruits of utopia cultivated by both part via cross-cultural communication, hand in hand composing a new chapter for the forthcoming near future.

\section{References}

Toynbee. (2010). Historical studies, Book 1. Shanghai: Shanghai Century Publishing Group.

Bloch, E. (2012). The principle of hope, Book 1. Shanghai: Shanghai Translation Publishing House.

Petrovich, V. V. (1959). On utopian socialism. Beijing: China Renmin University Press.

Plato. (2002). Republic. Beijing: The Commercial Press.

Hertzler, J. O. (1990). Utopian ideology. Beijing: The Commercial Press.

Andreae, J. V. (1991). Description of the Republic of Christianopolis. Beijing: The Commercial Press.

PENG, M. (1991). From utopia to science: A historical research on the development of chinese socialist thoughts. Beijing: China Renmin University Press.

More. (1982). Thomas,utopia. The Commercial Press.

Tommaso, C. (1960). The city of the sun. The Commercial Press.

QI, T. (2011). Economic history of ancient China. Jinan: Shandong University Press.

Collected Works of K. Marx and F. Engels (Vol. 2). (2009). Beijing:People's Publishing House.

\footnotetext{
${ }^{39}$ More,Thomas.Utopia. The Commercial Press, 1982: 44.

${ }^{40}$ Campanella,Tommaso. The City of the Sun. The Commercial Press, 1960: 35.

${ }^{41}$ Стёпин, В.C. "Marx and the Trend of Modern Civilization" in TheViewson Marxist Philosophy by Contemporary Scholars.Beijing :Beijing Normal University Publishing House, 2012:187.

${ }^{42}$ Collected Works of K.Marx and F.Engels Volume 1.Beijing:People's Publishing House, 1972:255.
} 